Journal of Research in Education and Society

Volume 11, Number 1, April 2020; ISSN: 2141-6753

Published By

International Centre for Integrated Development Research, Nigeria

In collaboration with

Copperstone University, Zambia

\title{
Teacher-Students' Relationship and Students' Academic Performance in Public Secondary Schools in Magu District, Tanzania
}

\author{
Mahona Joseph Paschal \\ Demetria Gerold Mkulu
}

\begin{abstract}
This study explored the influence of teacher - students' relationship on students' academic performance in Tanzania using Magu District as a case study. The sample for this study was 130 respondents that were drawn from six public secondary schools both by using rondom sampling and purposive sampling; 6 school Heads, 57 teachers, 66 students and one District Educational Officer. A descriptive survey approach was used in this study. In order to get information, the researcher used questionnaire and interview as instruments. The results of this study indicated that teacher-students' relationship is a crucial determinant and catalyst to academic performance in Tanzanian public secondary schools. The study identified among others that teacher - students relationships helps students to feel cared for by their teachers, helps students to have freedom of expression in the classroom and help teachers and students to be an integral part of the classroom as they participate actively. From the findings, it is concluded that despite the fact that teachers and students were aware of the elements of teacher-students relationships poor teacher - student relationships were still recorded in schools. Therefore, it is recommended that teachers should introduce close relationshis with students. Also, the study recommended that, performance of students can only be attained if teacher - students relationships will be maintained.
\end{abstract}

Keywords: Academic performance, Relationships, Teacher - student relationships, Public Secondary Schools

\section{INTRODUCTION}

The development of any society depends on the quality of education, and the quality of education depends on the quality of teachers, students and effective involvement of parents in education. Clinton and Hattie (2013). Teaching requires new teaching technique, teacher's perspectives, teaching strategies, and value for the classroom. Up to this time, many learning institutions and their managements are strongly focussing

Mahona Joseph Paschal and Sr. Demetria Gerold Mkulu (Ph.D) are Lecturers in the Department of Educational Foundation, St. Augustine University of Tanzania, Email. pajo.toronto@gmail.com, mkuludemetria@gmail.com.

This Article is Licensed under Creative Common Attribution-NonCommercial 4.0 International

20

https://creativecommons.org/licenses/by-nc/4.0/ 


\author{
Journal of Research in Education and Society \\ Volume 11, Number 1, April 2020; ISSN: 2141-6753 \\ Published By \\ International Centre for Integrated Development Research, Nigeria \\ In collaboration with \\ Copperstone University, Luanshya, Zambia
}

on measuring teachers' effectiveness and students' performance in schools (Burke, 2010). Teachers play a vital position in promoting education, learning and professional growth of learners. It is believed that, academic success of learners and schools is due to strong teacher-student relationship. Some of authors have shown the truth that the quality connection between educators and learning are a key elements to learning.

Aultman, Williams-Jonson \& Schutz, (2009) describes that the kind and worth of relationships formed by instructors and learners are key to successful teaching and learning. Through Aultman, Williams-Jonson, \& Schutz, (2009) we learn that, a teacher has skills, attitude and knowledge which can play a significant role in students' academic performance and how to make a meaningful life after school. Students who have close, supportive and positive relationships with their teachers attain higher level of achievements than those students with more conflicting relationships with teachers. Dianat \& Abedini (2016) describes that - to make a successful and effective learning happen, teachers need to be motivated, enthusiastic and engage students. Through my experiences as a teacher in public schools, I witnessed some students failed, and others were expelled from school because of improper behaviours that broke the quality of the relationship with teachers.

In Tanzania, many researches are ongoing and others have already been done in the field of Education to assess the affect of teacher-student relationship on school and academic performance, the scholars have witnessed that the lack of professional relationship between teachers and students have always been a challenge that has affected the sector of education in many negative ways. However, there is a well-built peception that the quality of teacher-student relatinships is essential for learning and teaching in the learning contexts. Santrock (2007) asserts that relationship behaviours of instructors greatly influence academic performance. Santrock further describes that, instructors - student relationships are essential to one's social and emotional maturity, they have the potential influence on how a student suceeds in school. This is to say that, interpersonal teacher-student relationships develop student experiences with success by giving continual monitoring as the students move into the academic pursuite in schools. Downey (2008) in his work says that, the quality of the relationship amongst a student and the teacher will results in a better degree of learning in the classroom.

Through the student-teacher interaction, our conceptualizations to motivation lead to quality learning (Downey, 2008). (Downey, 2008) concludes that the interpersonal relationship among teachers and students in the instructional settings affect the school and students learning. Nugent (2009) suggests that creating a sense of wellbeing in the relationship between teachers and students influences learning and academic performance. Teachers can motivate students during learning process. These 


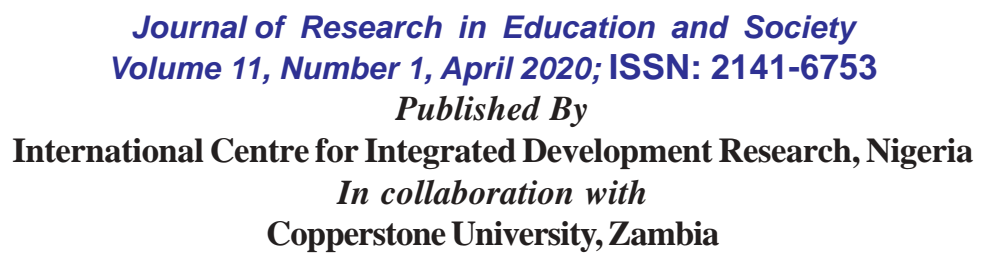

relationships help a teacher to know the students' need and help them to feel protected and confident in learning development. Larson (2011) says, nowadays, the existence of positive relationships inside the classroom is considered as possibly the most prominent factors in language learning, it may influence whichever in positive or negative ways, students' achievement and enthusiasm to work as well as advance their knowledge and social skills. O'Connor (2008), Newberry and Davis (2008) describe that teacher-student relationships are often mentioned as one of the core reasons for staying in the profession and they are a catalyst to learning, motivation and academic success. Downey (2008), Nugent (2009) and Larson (2011) have exposed a lesson that teachers get essential rewards from close relationships with their students and poor perfomances when relationships are lacking respect and professional friendship in the learning environment. Through the evidence from available literature, it seems that the formation of personal, supportive teacher - student relationships inherently demands emotional involvements from teachers. For students, it is evident that the effective quality of the teacher - student relationship is a vital factor in their school and academic success.

Tanzania has experienced an alarming increase in the number of students failing in public secondary schools since its independence. Despite the fact that the government has made a number of reforms in the system of education such as improvement of curriculum, allocation of funds, training and hiring of new teachers as well as construction of infrastructure in public secondary schools, the issue of poor students academic performance, poor teacher -student relationship continues to be a big challenge in public secondary schools in Tanzania as supported by Larson (2011) that nowadays the existence of positive relationships inside the classroom is considered as possibly the most prominent factors in performance of students, achievement and enthusiasm to work as well as advance their knowledge and social skills. In relation to that, most of the researches in Tanzania are done to assess the factors that contribute to the massive failure of students within public secondary schools. The majority focus on assessing learning materials and the environment than looking at how teacher-students' relationship can affect the academic performance of the learners. Therefore, this study intended to bring a perspective to how the teacher-students relationship influences students academic performance in public schools in Tanzania. The purpose was to determine the impact of teacher- student relationship on students' academic performance in public secondary schools in Magu District, Tanzania. Specifically, it aimed at:

i. Identifing the components of the teacher-student relationship that are essential to the teaching and learning profession in public secondary schools in Magu District

This Article is Licensed under Creative Common Attribution-NonCommercial 4.0 International 22 https://creativecommons.org/licenses/by-nc/4.0/ 


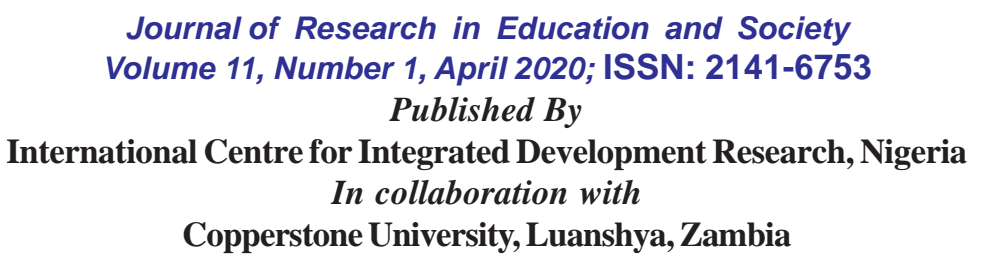

ii. Determining the contribution of teacher-student relationships to academic performance in public secondary schools in Magu District

iii. Assessing the challenges encountered by students who miss the teacher students relationship in Public secondary schools in Magu District.

iv. Establishing possible measures which could be used to enhance the teacherstudent relationship in public secondary schools in Magu District.

In line with the aim of the study, the following questions were utilized to guide the study

i. What are the components of the teacher - student relationship that are essential to the teaching and learning profession in public secondary schools in Magu District?

ii. What contribution does teacher-student relationships have on students' academic performance in public secondary schools in magu District?

iii. What challenges do students who are part of a poor teacher-students relationship face in public secondary schools in Magu District?

iv What possible measures could be used to enhance the teacher - student relationship in public secondary schools in Magu District?

\section{Essential Components of the Teacher-Student Relationship to Teaching}

The learner is a negotiator in the learning development and the objective of learning. Richard \& Rogers (2011) argue that learners have the responsibility to partake in classroom activities that are based on a cooperative rather than indibvidualistic approach to learning. Students have to be confortable with listening in the group. This stand point signifies that relationship is a need that students ought to strive for in order to achieve their goals. They need to be in relationship with their teachers to enable experience school in a positive way that can resulit in academic achievement.

Richard \& and Rodgers (2011) note that the teacher can also be assumed to be a counsellor, group process manager and effective communicator in the classroom. In such ways, teachers need to reflect on how they can assist their students toward success. This is an important component that maintains higher expectations for each student. They also have a big role in facilitating the communication process between students to act as an independent contributor within the learning environment and they inspire students to re-imagine their future. Macpherson (2007) notes that 'cooperative learning is part of a group of teaching and learning techniques where students interact with each other to acquire and practice the elements of a subject matter to meet common learning goals'. Cooperative learning is a very formal structuring of activities in a learning context that includes specific elements intending to increase the potential 


\author{
Journal of Research in Education and Society \\ Volume 11, Number 1, April 2020; ISSN: 2141-6753 \\ Published By \\ International Centre for Integrated Development Research, Nigeria \\ In collaboration with \\ Copperstone University, Zambia
}

\begin{abstract}
for rich and deep learning (Macpherson, 2007). It provides a chance to encourage and support each other in the learning environment. This point really shows the truth of interdependence in the group that members are responsible for each other's success. The teacher may observe and intervene if necessary to ensure that the task is done accordingly. Tickett and Moos (1973) as cited in Myers and Claus, (2012) state that the classroom environment consists of dimensions; the ability for students to develop relationships with their instructors and peers and the extent to which students can engage in learning activities, and the general structure of the classroom provided by the instructor.
\end{abstract}

Many learners still seem to depend completely on the teacher to impart knowledge (Narváez, 2009). Teachers carry the whole duty for education; while learners or students are supposed to listen and often do not even have any idea at first of what occurs in the classroom. However, this practice is changing owing to educational and social reforms that need to be developed. Nugent (2009) suggests that to create a strong relationship, teachers need to motivate during the learning process. Relationships are formed in the social groups of both teachers and students, and especially in educational contexts. As a result, teachers and students need to play more of an active role towards achieving academic success; they have to establish a more positive and professional relationship. Motivation plays a very crucial role in the process of building good relationships in school, as it encourages students to work very hard so that they could be given again.

Downey (2008), on his work 'Recommendations for fostering educational resilience in the classroom' suggests the use of reciprocal teaching as an effective instructional tool; one that requires the building of a strong interaction between teachers and students as they develop an inquiry - oriented approach to learning'. Based on my experience as a teacher, I learned that the teaching process that is set through structural dialogue technique between teachers and students is the key for providing the opportunity to create a good and professional relationship in the learning contexts. Having a socializing environment between teachers and students helps in instilling values and experiences such as motivation to learn actively in the classroom or learning environment.

Warshof and Rappaport (2013) have clearly explained the value of support and openness in order to create and cultivate a professional relationship between learners and teachers in the school. They impress on educational leaders the importace of providing support to teachers so that they may have a key help to maintain the formed relationship with the students. It is clear that strong and quality relationships need support to provide teachers with guidance on relationship building and maintaining strategies in the learning environment. O'Connor, Dearing and Collins (2011) confirm

This Article is Licensed under Creative Common Attribution-NonCommercial 4.0 International

24 


\author{
Journal of Research in Education and Society \\ Volume 11, Number 1, April 2020; ISSN: 2141-6753 \\ Published By \\ International Centre for Integrated Development Research, Nigeria \\ In collaboration with \\ Copperstone University, Luanshya, Zambia
}

\begin{abstract}
'the importance of fostering school teachers' awareness of the role of their relationships with students, and provide teachers with information on how to develop relationships in the classroom and school in general. Hallinan (2008) recommends learning to be a cognitive and socio-psychological process. His research has shown that students who like school have higher academic achievements. This means that creating supportive and professional relationships with students give teachers additional strengths that promote learning with joy and pleasure as of a wide range of students' interests. Larson (2011) says that attitude and achievements that students develop inside the school have an important impact on teacher-student relationships in schools.If students feel comfortable with the teacher and the school environment, they can make more positive and professional relationship such as friendship, develop a better way to behave and improve in their social thinking.

According to Fosnot (2005), fulfilment of students' expectations may be directly linked to motivation and performance in learning.' For example, providing motivation to the way students and teachers behave in the classroom can create a strong relationship because to a certain extent, they are influencing each other. Dillon (2010) confirms that 'it is during the first lesson when both students and teacher establish the basis for their relationship. The greetings, the role and what it is has expected of each other is discussed.' The basis of the relationship between teachers is made during the first time people meet.

For example, human beings have set up relationships based on what they shared from the first time of meeting. Hence teachers and students do the same in formulating their relationships in the learning contexts. Reeve (2006) has mentioned educator's characteristics that may help in creating healthy and productive relationships such as gentleness, discipline, relatedness and supportiveness. Hence, it is important to note that these characteristics seem to be the codes of caring.
\end{abstract}

\title{
The Contribution of Teacher-Students Relationship to Students' Academic Performance
}

A good and professional relationship is required to create safe contexts and give students confidence in their capability to work without pressure and become motivated to learn (O'Connor, Dearing and Collins, 2011). This especially happens when students are guided by positive emotional stimuli, they are better able to recall newly learned information (Nelson \& Lorber, 2009). Here, it should be emphasized that students feel motivated, influenced and stimulated to actively participate with their teachers when the teaching and learning environment is safe and supportive. That is the teacher

This Article is Licensed under Creative Common Attribution-NonCommercial 4.0 International 25 https://creativecommons.org/licenses/by-nc/4.0/ 


\author{
Journal of Research in Education and Society \\ Volume 11, Number 1, April 2020; ISSN: 2141-6753 \\ Published By \\ International Centre for Integrated Development Research, Nigeria \\ In collaboration with \\ Copperstone University, Zambia
}

\begin{abstract}
- student's relationship is vital to learning and academic performance. According to Fraser, Adridge and Soerjaningsih (2010), teachers should establish a professional relationship with their students, because the creation and maintenance of a positive classroom climate plays an important role in rendering the teaching and learning process more effective and efficienty. Hence, students in quality relationships with their teachers are helped in improving and fostering knowledge, attitude, skills and social development. Also, students with higher quality relationships take part more often and are more engaged in the learning perspectives than the students with a lower quality relationship. O'Connor (2008) states that personal relationships with students gives teachers internal rewards and gives meaning to their work. Based on this viewpoint, teacher - student relationship helps teachers create a sense of trust and increase the number of opportunities to sustain a meaningful role in the learning context.

Teacher-Student's relationships play a very important role in developing a mental picture of an individual. Ewnetu and Fisseha (2008) postulate that teachers have the basic needs for relatedness among the students in their class which can play an important role in students' s self-concepts, the expectation towards scholastic achievements as well as how to make a meaningful life after school. Hence, a student's self-esteem development is the overall sense of support a student feels from the important people around them. Myers and Pianta (2008) confirm that teacher - students relationship is fundamental to healthy development of students in school especially with regard to the student's self esteem. Lee (2007) notes that the trust developed in teacher - student relationships can contribute to students' academic performance. Student - teacher relationship can influence students' future paths towards academic excellence (Lee, 2007). Hence, as noted by Lee (2007), a good and professional relationship between teachers and students is essential in creating a safe context and gives confidence to learners to work without pressure and become motivated to learning.

Stipek and Miles (2008) propose that the type of relationship between the teacher and the student can greatly influence the behaviour of the student's sense of social acceptance in the learning contexts and academic performance. This means that teacher student relationship has long-term inferences for social and academic excellence. These relationships may reduce the risk of negative behavioural outcomes. Positive relationships have similar benefits for students. The student-teacher relationships play an important role of reducing the chances of future bad outcomes such like dropping out of school. Lastly, the effective teacher - students' relationships encourage greater confidence and classroom engagement in much the same manner as sensitive parenting creates an environment of safety and confidence.
\end{abstract}

This Article is Licensed under Creative Common Attribution-NonCommercial 4.0 International 


\author{
Journal of Research in Education and Society \\ Volume 11, Number 1, April 2020; ISSN: 2141-6753 \\ Published By \\ International Centre for Integrated Development Research, Nigeria \\ In collaboration with \\ Copperstone University, Luanshya, Zambia
}

\title{
The Challenges Encountered by Students Who Missed the Teacher-Students Relationship
}

Buyse, Verschueren, Verachtert \& Van Damme (2009) infer that children who experience conflicts in teacher - student's relationships in their first grade demonstrate lower achievement. This means that students who perceive their relationship negatively are found to have lower performance in their studies than those with quality involvement. Ewnetu and Fisseha (2008) assert that a positive relationship is associated with better performance and a negative relationship is related to a downward trend in achievement. Hence, there is no doubt that students who lack quality teacher - student relationship are experiencing lower academic performance.

Zeichner (2011) conducted a study on improving teacher education in the United State and comes up with the findings that students who miss the teacher- students relationship fear their teachers. The findings show that fear affect them to participate effectively in the classroom and outside the classroom. Hence, he concludes that students become free when teachers involve students in the classrooms and make they to be his or her friends. The fear of students who miss teacher- student relationship caused by heavy punishments, use of abusive language, humiliation and feveratision affects academic performance. Also, Dillon (2010) conducted a study on what works in the classroom and comes up with the findings that students who miss teacher - student relationship alway feel lonlely in the classroom. Most of them dropout of school because they lack support and assistance from their teachers.

The study conducted by Kalinga (2013) on the causes of drop- out in secondary schools in Tanzania discovers that most of the students who drop out from school are influenced by external factors such as empoloyment opportunities, life difficulties and lack of parents' awareness on education; poor relationship with their teachers and students in school. Students find that the best way to get peace is to leave the school and interact with other members in the community. The study conducted by Battin-Pearson (2000) had different findings that the major factors influencing dropout to students beyond 23 years is poor academic achievement, followed by poor relationship with teachers and fellow students; students who had deviant friends were more likely to drop out of school early regardless of their achievement in school.

Borman \& Overman (2004) conducted a study on Academic resilience in mathematics among poor and minority students and come up with the findings that there is greater relationship between teacher- student relationship and students' academic performance. They identify that students who miss teacher - students relationship are in a great position to fail their final examinations. Therefore, the study concluded that poor performance of some students in schools is caused by teachers 


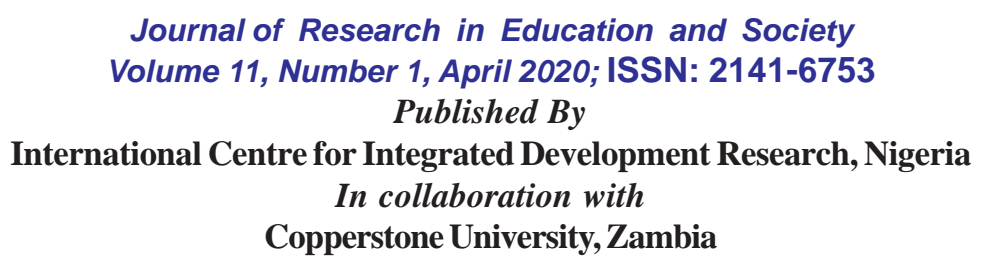

who treat their students negative. Downey (2008) conducted a study on the recommendations for fostering educational resilience in the Classroom and reports that teachers should show good relationship with their learners. The findings show that teachers with poor relationship with their learners lead them into failure). Downey (2008) indicates that students are the one who are mostly affected if the teachers do not show good relationship to their learners.

\section{Possible Measures that could be used to Enhance Teacher-Student Relationship in School}

One of the main intentions in teaching and learning is to bring both professional growth and academic progress in learners. Therefore, there is a big need to create secured settings and measures that may establish positive relationships and enhance the learning and teaching process. Gitonga (2012) carried out a study on the influence of teacher's motivation on students' academic performance in Kenya andfinds that good living conditions, good salary and professional development for teachers has an impact on learner's achievement because these cause teachers to like their work and influence their students to be a fundamental part of the school. Adeyinka, Asabi and Adedotun (2013) state that when right quantity and quality of human resources are brought together, it may manipulate other resources towards realising institution objectives and goals. So, this gives the direction that the relationships in school are infused by the bringing together; the quality and quantity of human resources.

Richard and Rodgers (2011) argues that learners have to take part in classroom activities based on the supportive rather than individualistic approach to learning. Every learner must have participation with his/her teachers in the classroom, cooperative learning in a learning contexts allows the formation of groups that are responsible to solve tasks in the school and for providing support to one another. According to Murray and Pianata (2009) classroom structures, routines, rules and activities convey a sense of community and continuity to students. Murray and Pianata (2009 also considers that such structures can also promote positive relationships within the classroom. It is evident that a well-organized classroom provides students with a consistent safe setting where expectations for appropriate behaviours are clearly stated and reinforced. Through this, teachers are also provided with various numbers of opportunities to develop and sustain relationships with their students in the classroom. Motivation is an inter nal state that produces energy that gives impetus for action and further determines directions and intensity of behaviour or undertaken actions (Dianat and Abedini, 2016). This means that motivation is that guiding principles that enable people to stay focused on the path of success regardless of the challenges that 


\author{
Journal of Research in Education and Society \\ Volume 11, Number 1, April 2020; ISSN: 2141-6753 \\ Published By \\ International Centre for Integrated Development Research, Nigeria \\ In collaboration with \\ Copperstone University, Luanshya, Zambia
}

maybe encountered. However, Fosnot (2005) supports that students may feel more comfortable and motivated to learn when teachers make some kind of effort to reward and encourage them, demonstrate patience during teaching and managing behaviour. Marzano R. and Marzano J. (2003) explain that, in order to foster a positive relationships between teachers and students inside the classroom, the teacher needs to be aware of both academic and emotional needs of the students such as empathy, as well as how they have to be treated inside and outside classroom. This means that, caring and treating the students in a friendly, respecting and being sincere and professional may make the relationships stronger and more positive.

\title{
METHOD
}

This study employed causal research design whereby six secondary schools in the Magu District of Tanzania were investigated. The participants from the selected schools, probability and non probability sampling techniques were used to select 130 respondents from the 6 public secondary schools. The respondents include 6 school heads, 57 teachers, 66 students and one District Educational Officer. Students and other teachers were selected by rondom sampling technique. This technique eliminated all research bias in selection of respondents for this study, and the sample frame reflected the target population of the study. In non-probability sampling technique purposeful sampling was used to select Head of schools and District Educational Officer. The instruments for data collection are questionnaires and interviews. Quantitative data were presented using percentage and frequencies where statistical figures as well as tables were produced as output of the input information. Qualitative data that were obtained from the interview guide was analysed by descriptive and summarization content analysis based on the research objectives.

\section{RESULTS AND DISCUSSION}

\section{The Components of the Teacher - Student Relationship that are Essential to the Teaching and Learning Profession}

The respondents mentioned various components that make-up the teacher - student relationship in the schools context. The research has grouped these components into four categories such as classroom climate, instructional delivery, teacher interactions and classroom structure arrangement. Classroom Climate refers to the culture of caring and respect that a teacher builds with the students in the classroom. Under classroom climate category, the participants were able to mention the following components that are the key to teacher-student's relationships as represented in Table 1. 


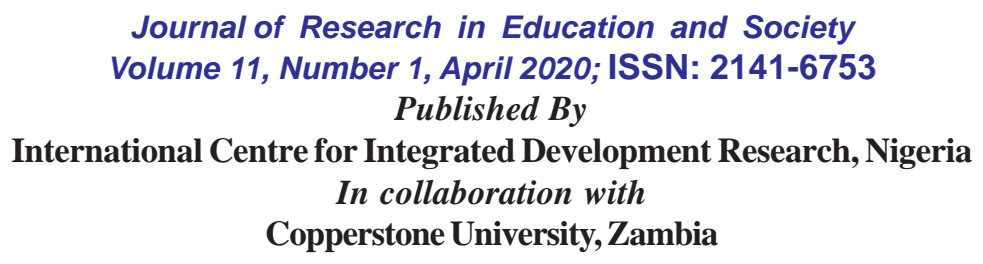

\begin{tabular}{lll}
\hline Table 1: Essential Components under Classroom Climate & \\
Components & Frequency & Percentage \\
Building a sense of togetherness in the classroom & 24 & 42 \\
Creating a sense of trust with students & 20 & 35 \\
Creating student tasks for sense of ownership & 50 & 87.7 \\
Creating constructive routines and methods & 7 & 14
\end{tabular}

Source: Researcher, 2019

Table 1 shows that $42 \%$ of the teachers responded that building a sense of inclusivness in the classroom is the essential component of teacher-student relationships while $35 \%$ said creating a sense of trust with students, $87.7 \%$ responded by saying that to create student's tasks for a sense of ownership is a component necessary to the establishment of teacher - students relationships in the school context, while 14\% constructive routine and methods. This simply means that majority of teachers in public schools know the components of teacher-students relationships in schools. During the interview with the Heads of Schools, the respondents explained that building a relationship within the classroom and school contexts begins with the classroom contexts. One respondent explains that 'in order to establish teacher - students relationship in the classroom, both teachers and students have to build trust that helps to foster independence in the learning contexts, and responsibilities to complete their tasks as assigned. Responsibility and accountability in accomplishing tasks give both teachers and students a sense of ownership in the classroom, such that everyone feels a part of the class.'

The classroom climate also has clear aims and expectations that are established together through routines and methods. Respondents stated that 'both teachers and students create rules, aims and expectations during the first week of being in the classroom and school. Teachers provide information and regulations to follow during learning processes to adjust behaviour and reinforce the culture of support and respect. Newberry and Davis (2008) argue that the effective quality of the teacher - student relationship is an important factor in their school and academic success. Relatively, little is known regarding the interpersonal demands that teachers may experience from their students. This means that teachers and students both need to know what is expected during time of teaching as well as in the learning processes.

Delivering instruction is a category that contains methods of interaction that help to build teacher - student relationship between a student and a teacher in the learning environment. The essential interaction between a learner and a teacher has direct impact on learning at every moment of establishing relationship in school.

This Article is Licensed under Creative Common Attribution-NonCommercial 4.0 International 


\section{Journal of Research in Education and Society \\ Volume 11, Number 1, April 2020; ISSN: 2141-6753 \\ Published By \\ International Centre for Integrated Development Research, Nigeria \\ In collaboration with \\ Copperstone University, Luanshya, Zambia}

\begin{tabular}{lll}
\hline Table 2: Essential components under Delivering Instruction \\
Items & Frequency & Percent \\
Monitoring & 70 & 53.8 \\
Activelistening & 80 & 61.5 \\
Re-teaching & 57 & 43.8 \\
Motivating students & 125 & 96.1 \\
Student's interest & 96 & 73.8 \\
Equitability & 68 & 52.3
\end{tabular}

Source: Researcher, 2019

The field results as shown on table 2 reveal that most of the respondents understand the components of teacher - students' relationships in public secondary schools. More than $96 \%$ of the respondents agree that motivating students is a key component to the teacher - students relationships in public schools, $73.8 \%$ say caring about student interests is a key component to the teacher - students relationships in public schools, while $61.5 \%$ note that active listening is a key component to the teacher - students relationships in public schools. In the same vein, 53.8\% mention monitoring, $52.3 \%$ agree on equitability and $43.8 \%$ on re-teaching. Furthermore, Nugent (2009) supports that creating a sense of wellbeing in the relationship between teachers and students influences learning and academic performance. During an interview, one of the Heads of Schools says that a teacher acts as an assistant that plays a part and role in giving guidance to the students. One of the participants wrote that 'I am always looking carefully what the student are doing and I help them (with) what they can't do'

Re-teaching also is an important component that can accelerate the desire to build relationships between the teacher and a student. In the study, participants stated that when they do not understand the lesson, the teacher would come and repeat the lesson to help students understand it. Another school head says 'I usually use a new method to teach my students when I see the one I used didn't help them understand the lesson.' Creating learning opportunities that foster students' interests also reflects the relationship that teacher and students build in the learning contexts was another response given during interview by the District Educational Officer in Magu District. The District educational officer said; 'Our teacher would think of what we needed in the classroom and he used to help us do well in the class. He was a good listener in terms of what we liked and he used to motivate us as he taught and gave moral support.'

Equitability refers to a learner's equal opportunity to be involved in the class by providing an answer or paricipating in other ways . Providing equal opportunities to every student help in the promotion of care and the building of relationship among 


\author{
Journal of Research in Education and Society \\ Volume 11, Number 1, April 2020; ISSN: 2141-6753 \\ Published By \\ International Centre for Integrated Development Research, Nigeria \\ In collaboration with \\ Copperstone University, Zambia
}

them. For example, some of the participants stated that 'our teachers used to move from desk to desk to see and check what we are doing. They help us by giving lessons through watching videos, and listening to the radio. The findings reveal that majority of the students and teachers are aware of the essential components of building teacherstudents' relationships in public secondary schools. Fosnot (2005) portrays that the fulfilment of students' expectations may be directly linked to motivation and performance in learning. Therefore, this research realized that most of the participants are aware of the essential components of teacher - student's relationships that influence academic performance in public secondary schools in the Magu District.

Table 3: Contribution of Teacher-Student Relationships to students' academic Performance

Helps students feel a strong connection to the teachers.

\begin{tabular}{llll}
\multicolumn{2}{c}{ Students } & \multicolumn{2}{r}{ Teachers } \\
Variable & Percentage & Variable & Percent \\
& - & 50 & 87.7 \\
& - & & \\
& - & 48 & 84.2 \\
36 & 54.5 & - & - \\
& & & \\
- & - & 54 & 94.7 \\
30 & 45.4 & - & - \\
46 & 69.9 & - & -
\end{tabular}
participate actively

Source: Researcher, 2019

Table 3 reveals that $87.7 \%$ of the respondents agree that teacher -student's relationships help students feel a strong connection to the teacher in the classroom, $84.2 \%$ indicate that teacher - students relationships help students to feel cared about by their teachers in the learning contexts, $94.7 \%$ say that teacher - student's relationships help students to feel ownership in the classroom. Interstingly, 54.5\% indicate that teacher - students' relationships build trust and responsibility among teachers and students from day one of being in the school environment, $45.4 \%$ indicate that the teacher students relationships make students feel ownership in the classroom, while $69.9 \%$ indicate that teacher - students relationships allow teacher and students to be an integral

This Article is Licensed under Creative Common Attribution-NonCommercial 4.0 International 32 https://creativecommons.org/licenses/by-nc/4.0/ 


\author{
Journal of Research in Education and Society \\ Volume 11, Number 1, April 2020; ISSN: 2141-6753 \\ Published By \\ International Centre for Integrated Development Research, Nigeria \\ In collaboration with \\ Copperstone University, Luanshya, Zambia
}

\begin{abstract}
part of the classroom. This conforms with Myers and Pianta (2008) who say that teacher-students relationships are fundamental to healthy development of students in school especially to the students' self-esteem. Therefore, it is concluded that majority of participants both teachers and students know that the components of teacherstudents relationships are key elements of school in ensuring student academic performance.
\end{abstract}

Table 4: Challenges Facing Students who Missed out on Teacher-Students' Relationships in Public Secondary Schools

Challenges

Poor performance

School dropout

\begin{tabular}{cccc}
\multicolumn{2}{c}{ Students } & \multicolumn{2}{c}{ Teacher } \\
Frequency & Percent & Frequency & Percent \\
64 & 96.6 & 55 & 96.4 \\
60 & 90.9 & 46 & 80.7 \\
40 & 60.6 & 50 & 87.7 \\
56 & 84.8 & 54 & 94.7 \\
30 & 45.4 & 42 & 73.6 \\
46 & 69.6 & 57 & 100
\end{tabular}

Immoral behaviour

Loneliness

Stress

Lack of confidenceand lack of

professional support

Source: Researcher, 2019

In this study which involved teachers, students, School Heads and the District Education Officer, $96.6 \%$ of the students and $96.4 \%$ of the teachers point out that poor performance is one of the biggest challenges that students who missed out on teacher - students' relationships in the learning context are facing, while $90.9 \%$ of students and $80.7 \%$ of teachers maintain that school dropout is a challenge that students who missed out on teacher - students' relationships in schools are facing. In the same vein, $60.6 \%$ of students as well as $87.7 \%$ of teachers have shown that one of the challenges is immoral behaviour due to the influence of peer pressures. Loneliness is another challenge that was mentioned by $84.8 \%$ of student and $94.7 \%$ of teachers; $45.4 \%$ of students and $73.6 \%$ of teachers strongly maintain that students who missed out on teacher-student's relationships experience stress in their life and as a result they lack professionals (contacts) that can influence their academic development. Lack of confidence and professional support from the teachers is a challenge that students who missed supportive relationships with their teachers are facing. In this study, while $69.6 \%$ of students and $100 \%$ of teachers mentioned lack of confidence and lack of professional support as a major challenge concern, only 2 students did not mention any of the challenges. To support these ideas Buyse et al. (2009) argue that children who experience conflicts in teacher- students' relationships in the first grade demonstrate lower achievement. 


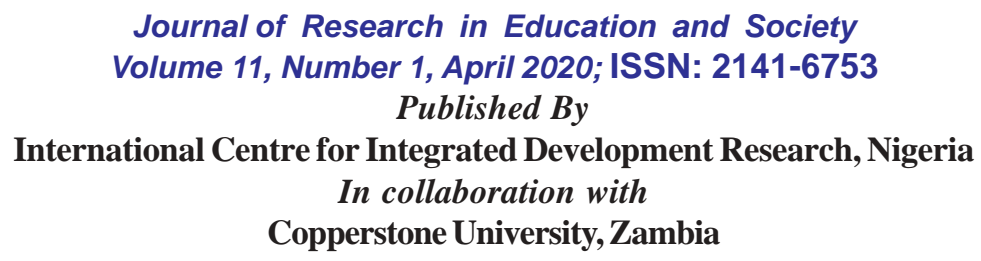

\begin{tabular}{|c|c|c|c|c|}
\hline \multirow[t]{2}{*}{ Strategies } & \multicolumn{2}{|c|}{ Students } & \multicolumn{2}{|c|}{ Teacher } \\
\hline & Frequency & Percent & Frequency & Percent \\
\hline Guidance and counseling & 62 & 93.9 & 55 & 96.4 \\
\hline Respect one another & 60 & 90.9 & 46 & 80.7 \\
\hline Caring & 64 & 96.9 & 54 & 98.1 \\
\hline Team work and motivation & 56 & 84.8 & 52 & 91.2 \\
\hline Maintain discipline & 54 & 81.8 & 51 & 89.4 \\
\hline Professional support & 48 & 72.7 & 50 & 87.7 \\
\hline
\end{tabular}

Source: Researcher, 2019

The table 5 shows that $96.4 \%$ of teachers mention that guidance and counselling are among the strategies that teachers use to improve teacher - students relationships in public secondary schools, $98.1 \%$ of teachers also strongly mention that caring for each other improves the relationships between teachers and students, $89.4 \%$ of teachers suggest that maintaining discipline between teachers and students is a key to a supportive relationship, $87.7 \%$ mention professional support while $91.2 \%$ strongly maintain motivation and team work are the essential strategies for maintaining teacher - student relationships in public secondary schools, $93.9 \%$ of students mentioned guidance and counselling as a strategy for enhancing teacher - students relationships in public secondary schools while $90.9 \%$ mention respect as a key to teacher - students' relationships (Dianat and Abedini, 2016). Supports this by saying, motivation is that guiding principles that enable people to stay focused on the path of success regardless of the challenges that maybe encountered. However, Fosnot (2005) supports that students may feel more comfortable and motivated to learn when teachers make some kind of effort to reward and encourage them, demonstrate patience during teaching and managing behaviour.

\section{CONCLUSIONAND RECOMMENDATIONS}

Teacher-student relationship is clearly known and practised in public schools in Magu District. It can be concluded that teacher-student relationship is an essential ingredient for promoting good academic performance of students in secondary schools. Either absence or poor teacher-student relationship results into devastating problems among teachers and students which in turn impede the teaching and learning process. Therefore, poor academic performance may be experienced among students. It is the role of every education stakeholder to develop and practise viable strategies to enhance good and effective teacher-student relationship. The use of modern teaching methods like discussion, debate and practicals can enhance such relationship.

Supportive interactions between teacher and students are important to students'

This Article is Licensed under Creative Common Attribution-NonCommercial 4.0 International 


\author{
Journal of Research in Education and Society \\ Volume 11, Number 1, April 2020; ISSN: 2141-6753 \\ Published By \\ International Centre for Integrated Development Research, Nigeria \\ In collaboration with \\ Copperstone University, Luanshya, Zambia
}

academic performance in general. Teachers, students, policy makers, parents, caregivers and school managers should try their best to establish supportive relationships in the learning contexts to enhance academic performance in public secondary schools. Policy makers should work hard to establish ways in educational settings to offer teachers the clearest information on how to establish and develop professional relationships with students in the school. Efforts should be made by the teachers and caregivers to instil the value and understanding of teacher - students' relationships for enhanced students' academic performance. Seminars, workshops should be conducted to help both teachers and students on healthy teacher-students relationships.

\title{
REFERENCES
}

Adeyinka R. A., Asabi, O. \& Adedotun, O. (2013). Teacher motivation on student's performance in mathematics in government secondary schools, Makurdi Lg area. International Journal of Humanities and Social Science invention, 2(5), 3541

Aultman, L., Williams-Jonson, M., \& Schutz, P. (2009). Boundary dilemmas in teacher - students relationships: struggling with "the line". tTeaching and teacher Education, 25(5), 636-646.

Battin-Pearson, Sara., (2000). "Predictors of Early High School Dropout: A Test of Theories" Journal of Educational Psychology, 1(2), 53- 75.

Borman, G. D., \& Overman, L. T. (2004). Academic resilience in mathematics among poor and minority students. Elementary School Journal, (10)4, 177-195.

Burke, Roland, (2010) Decolonization and the evolution of International Human Rights., United States of America; University of Pennsylvania Press

Buyse, E., Verschueren, K., Verachtert, P., \& Van Damme, J. (2009). Predicting school Adjustments in early elementary school: Impact of teacher-child relationship quality and relational classroom climate. Elementary school journal, 110(2), 119-141. http://dx.doi.org/10.1086/605768

Clinton, J \& Hattie, J (2013) New Zealand Students' perceptions of parental involvements in learning and schooling. Asia Pacific Journal of Education 33(3) 324-337

Creasy, G, (2009). A measure to assess Student- instructor relationships. International journal for the scholarships of Teaching and learning 3(2),

Dianat, M., \& Abedini, M. (2016). The relationship of teachers' behaviour and performance with intrinsic motivation of primary school students of Bandar Abbas City: International Journal of Humanities and cultural studies. Special Issue, 2377-2384.

This Article is Licensed under Creative Common Attribution-NonCommercial 4.0 International 


\author{
Journal of Research in Education and Society \\ Volume 11, Number 1, April 2020; ISSN: 2141-6753 \\ Published By \\ International Centre for Integrated Development Research, Nigeria \\ In collaboration with \\ Copperstone University, Zambia
}

Dillon, S. (2010). What works in the classroom? Ask the students. The New York Times. Retrieved from http://www.nytimes.com/2010/12/11/education/ 11education.html

Downey, J. A (2008) Recommendations for fostering educational resilience in the classroom. Preventing School failure. 53, 56 -63.

Ewnetu L, \& Fisseha, J (2008). The teacher-relationship behaviour and parenting style correlates of students' scholastic achievement at Grade seven English. Ethiopia. Journal of. Education and Science, 4(1), 39-50.

Fosnot, C. J. (2005) Constructivism theory, perspectives and practice. New York Teachers College Press

Fraser, B. J, Adridge, J. M, \& Soerjaningsih, W. (2010), Instructor- teacher interpersonal interaction and students outcomes at the university level in Indonesia. The Open Education Journal, 3, 21-33

Gitonga, D. W (2012). Influence of teacher's motivation on student's performance in Kenya Certificate of Secondary Education in Public Secondary in Imet South District Kenya: Research Project for the Degree of Master of education in educational administration: University of Nairobi.

Hallinan, M. T (2008), Teacher influences on student's attachment to school. Sociology of Education, 81(3), 271-283

Kalinga, T. S (2013) Causes of drop-outin secondary schools in Tanzania: The case of Mbeya, Dar es - Salaam and Kilimanjaro. Unpublished Masters' Dissertation, Open University of Tanzania.

Larson, R. (2011) Teacher- student relationship and student achievement. Omaha, NE: University of Nebraska

Lee, S. J (2007). The relations between the students-teacher trust relationships and school success in the Case of Korean Middle Schools. Educational Studies, 33(2):209-216. DOI: 10.1080/03055690601068477.

Macpherson, A. (2007) Cooperative learning group activities for college courses: A guide for instructors. Kwantlen University College.

Marzano, R.J. \& Marzano J. S. (2003). The key to classroom management. Educational Leadership, 61(1), 6-13. Available online at: http://www.ascd.org/ publications/educational-leadership/sept03/vol61/num01/The-Key-toClassroom-Management.aspx.

Murray, C. \& Pianta, R. C. (2009). The importance of teacher student's relationships for adolescence with high incidences disabilities: Theory into Practice. Adolescent Mental Health (Spring, 2007), 46(2), 105-112.

Myers, S. A., \& Claus cC, jJ. (2012). The relationship between student's motives to communicate with their instructors and classroom Environment. Communication Quarterly, 60 (3), 386-402.

This Article is Licensed under Creative Common Attribution-NonCommercial 4.0 International 


\section{Journal of Research in Education and Society \\ Volume 11, Number 1, April 2020; ISSN: 2141-6753 \\ Published By \\ International Centre for Integrated Development Research, Nigeria \\ In collaboration with \\ Copperstone University, Luanshya, Zambia}

Myers, S. S \& Pianata, R. C (2008). Developmental commentary; individual and contextual influences on student -teacher relationship and children's early problem behaviours. Journal of clinical \& Adolescent Psychology. 37, 600-608. http:I /dx.doi.org/10.1080/15374410802148160

Narváez, O. M. (2009). University students' beliefs about teaching and teachers. In R. Reyes (Ed.), Creencias, estrategias y pronunciación en el aprendizaje de lenguas extranjeras (pp. 183-206). Chetumal, MX: Universidad de Quintana Roo

Nelson, K. A \& Lorber, W. (2009). Enhanced Post-learning memory consolidation is influenced by arousal predisposition and emotion regulation but not by stimulus valence or arousal (p. 70-79). N. p. Neurobiology of Learning \& Memory, 92, Retrieved March 1, 2015

Newberry, M., \& Davis, H. A. (2008). The role of elementary teacher's conceptions of closeness to students on their differential behaviour in the classroom. Teaching and Teacher Education, 24, 1965-1985.

Nugent, T. T. (2009). The impact of teacher-student interaction on student motivation and achievement (Doctoral Dissertation) University of General Florida, Orlando.

O’Connor, E. E, Dearing, E., \& Collins, B. A, (2011). Teacher-child relationship and behaviour problem trajectories in elementary school. American Educational Research Journal, 48(1), 120-162

O'Connor, K. E. (2008) "You choose to care" Teacher, emotions and professional identity. Teaching and Teacher Education, 24, 117-126

Reeve, J. (2006) Teachers as facilitators: what autonomy -supportive teachers do and why their students benefits. The elementary school journal, 106(3), 225236

Richard, J. C \& Rodgers, T. E. (2011). Approaches and methods in language teaching: Cambridge Language Teaching Library. $2^{\text {nd }}$ Edition. Cambridge University Press

Santrock, J. W. (2007) A topical approach to life-span development (3rd Edition) New York McGraw-Hill.

Stipek, D., \& Miles, S. (2008) Effects of aggression on achievement: Does conflicts with the teacher make it worse? Child Development, 79, 1721-1736. http:// dx.doi.org/10.1111/j.1467-8624.2008.01221.x

Warshof, A., \& Rappaport, N. (2013). Staying connected with troubled students. Educational Leadership, 71(1), 34-38.

Zeichner, K. (2011). Improving teacher education in the United States. Essay commissioned by the American Education Research Association. Retrieved from http://www.aera.net/Portals/38/docs/Annual Meeting/Zeichner AERA essay1b.pdf 